\title{
Immature monocyte derived dendritic cells gene expression profile in response to Virus-Like Particles stimulation Eleonora Aricò ${ }^{1,2}$, Ena Wang1, Maria Lina Tornesello ${ }^{3}$, Maria Tagliamonte ${ }^{3}$, George K Lewis ${ }^{4,5}$, Francesco M Marincola1, Franco M Buonaguro ${ }^{3}$ and Luigi Buonaguro*3,4
}

\author{
Address: ${ }^{1}$ Immunogenetics Section, Department of Transfusion Medicine, Clinical Center, National Institutes of Health, Bethesda, MD 20892- \\ 1502, USA, ${ }^{2}$ Department of Cell Biolology and Neurosciences, Istituto Superiore di Sanita, Rome, Italy, ${ }^{3}$ Lab. Viral Oncogenesis and \\ Immunotherapies \& AIDS Reference Center, Department of Experimental Oncology, Istituto Nazionale Tumori "Fond. G. Pascale", 80131 Napoli, \\ Italy, ${ }^{4}$ Institute of Human Virology, University of Maryland Biotechnology Institute and ${ }^{5}$ Department of Microbiology and Immunology, \\ University of Maryland School of Medicine, University of Maryland Baltimore, Baltimore, MD 21201, USA \\ Email: Eleonora Aricò - aricoe@cc.nih.gov; Ena Wang - EWang@mail.cc.nih.gov; Maria Lina Tornesello - irccsvir@unina.it; \\ Maria Tagliamonte - irccsvir@unina.it; George K Lewis - lewisg@umbi.umd.edu; Francesco M Marincola - FMarincola@mail.cc.nih.gov; \\ Franco M Buonaguro - irccsvir@unina.it; Luigi Buonaguro* - irccsvir@unina.it \\ * Corresponding author
}

Published: 29 December 2005

Journal of Translational Medicine 2005, 3:45 doi:10.1 186/1479-5876-3-45

Received: 30 September 2005

Accepted: 29 December 2005

This article is available from: http://www.translational-medicine.com/content/3/1/45

(C) 2005 Aricò et al; licensee BioMed Central Ltd.

This is an Open Access article distributed under the terms of the Creative Commons Attribution License (http://creativecommons.org/licenses/by/2.0), which permits unrestricted use, distribution, and reproduction in any medium, provided the original work is properly cited.

\section{Introduction}

Virus-like particles (VLPs) represent a peculiar form of subunit vaccine based on viral capsid and envelope proteins which show the ability to self-assemble into highly 
organized particulate structures $[1,2]$. VLPs closely resemble immature virus particles but are both replication and infection incompetent, lacking regulatory proteins as well as infectious genetic material. VLPs can be employed to deliver additional antigenic structures, such as whole proteins or specific individual epitopes and have been shown to generally induce more effective humoral and cellular immune response than their soluble counterparts [3].

Considering all these properties, VLPs represent a highly attractive vaccine approach and have been produced from a broad spectrum of enveloped and non-enveloped viruses, regardless of whether the particle structure is based on single or multiple capsid proteins [4].

The VLPs developed in our laboratory are based on the Human Immunodeficiency Virus type 1 Pr55gag precursor protein (HIV-VLPs) and present an entire gp120 molecule, anchored through the trans-membrane (TM) portion of the Epstein-Barr virus (EBV) gp220/350 [5]. The gp120 glycoprotein selected for these HIV-VLPs derives from an Ugandan HIV-1 isolate of the A clade $[6,7]$, which represents the second most prevalent HIV-1 subtype worldwide (approx. 25\%) and is predominant in many developing countries (HIV-VLP $\mathrm{AL}_{\mathrm{A}} \mathrm{s}$ ).

The HIV-VLP $\mathrm{A}_{\mathrm{A}} \mathrm{s}$ show a strong in vivo immunogenicity in Balb/c mice, even in absence of adjuvants, and HIV-1-specific T cell response (CD4+ and CD8+) as well as crossclade neutralizing antibodies have been detected in immunized animals [8]. Moreover, the intra-peritoneal and the intra-nasal administrations of HIV-VLP $\mathrm{A}_{\mathrm{A}} \mathrm{s}$ induce in mice an antibody response at systemic as well as local (vaginal and intestinal) level [9].

Most of the VLPs developed have been shown to be highly effective at stimulating CD4 proliferative responses and cytotoxic T lymphocyte (CTL) responses in addition to Bcell-mediated humoral immunity [4]. These properties suggest the ability to promote the activation of antigenpresenting cells (APCs) and a cross-presentation of peptides in association to both MHC class I and -II molecules $[10,11]$.

We have recently shown that baculovirus-expressed HIV$\mathrm{VLP}_{\mathrm{A}} \mathrm{s}$ are able to induce maturation of DCs, resulting in expression of surface maturation markers as well as increased production of Th1 polarizing cytokines, and this effect is partially mediated by the intra-cellular TLRs 3 and 8 . The HIV-VLP-activated DCs induce a primary and secondary response in autologous CD4+ T cells, in an in vitro immunization assay. Finally, the uptake of HIV-VLPs by DCs appears to be mainly mediated by an endocytosismediated pathway (Buonaguro L, et al., submitted).
Dendritic cells (DCs) are professional antigen-presenting cells (APC) able to initiate immune responses $[12,13]$. Immature DCs are located in peripheral tissues to continuously monitor the environment through the uptake of particulate and soluble products. Antigen-loaded DCs acquire a mature phenotype, associated with reduced endocytic and phagocytic capacities, and enhanced production of inflammatory cytokines and chemokines [1417]. The mature DCs, then, migrate toward the lymphoid organs where they interact with, and activate, naïve T cells [18].

The analysis of the transcription profile, defined as transcriptome, is highly informative of the molecular basis underlying the morphological, phenotypical and functional changes of specific immune cell populations induced by specific stimuli. In particular, gene-expression profiles of human Th1 and Th2 cells have allowed the identification of genetic patterns involved in the differential T helper cell polarization [19]. Similarly, selected genes differentially regulated during the transition from a $B$ cell to plasma cell have been identified, which are involved in the Ab secretion, homeostasis, migration, and differentiation [20].

More recently, the expression pattern of specific sets of genes upon DC differentiation and maturation has been reported, showing a great plasticity of the DC transcriptional programs, activated in response to CD40L, LPS and cocktail of inflammatory cytokines and prostaglandin (PG) E(2) (CyC) [21,22]. Furthermore, a time-specific kinetic of response has been observed in MDDC activated with pathogen components, showing a rapid upregulation of genes associated with the innate arm of the immune response, followed by induction of adaptive immune response genes [23-25].

In this study, we have analyzed the changes in the gene expression of immature human monocyte-derived DC (MDDC) activated with the baculovirus-expressed HIVVLPs developed in our laboratory. The transcriptional pattern has been evaluated after 4 and 8 hours of induction with HIV-VLPs and the results show the sustained increased expression of specific genes involved in the morphological and functional changes characterizing the MDDCs activation and maturation.

\section{Materials and methods Cell culture medium}

DC culture medium consisted of RPMI 1640 medium (Life Technologies, Carlsbad, Calif.) supplemented with 2 mM L-glutamine (Sigma), 1\% nonessential amino acids (Life Technologies), $1 \%$ sodium pyruvate (Life Technologies), $50 \mu \mathrm{M}$ 2-mercaptoethanol (Sigma), $50 \mu \mathrm{g}$ of gen- 
CD 80

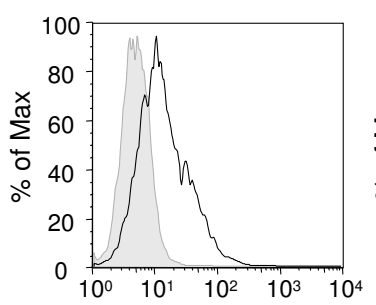

PBS

HIV-VLPs

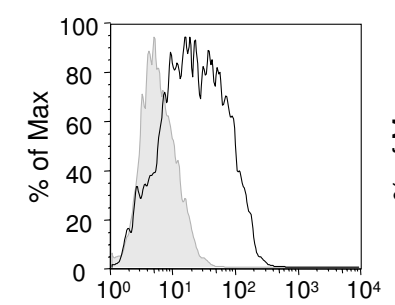

CD 83
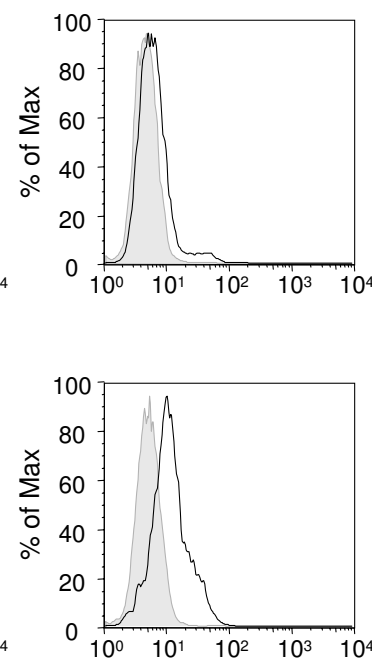

CD 86
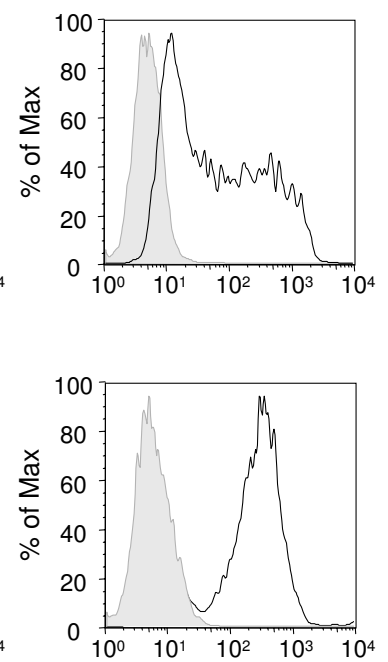

HLA-DR
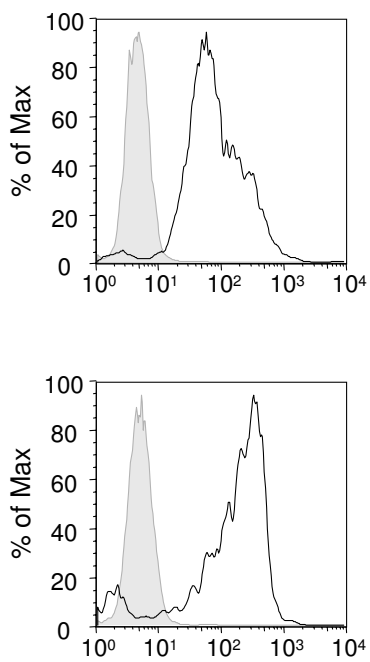

Figure I

Maturation of DCs by baculovirus-expressed HIV-VLPs. Immature MDDCs were incubated in the presence of the indicated stimulus for 16 hours. The expression of CD80, CD83, CD86 and HLA-DR was analyzed on fixed cells by FACScalibur flow cytometer and data analysis was carried out with Flowjo software. The results of a representative experiment are shown; the shadowed curve represents the untreated cells.

tamicin (Life Technologies) per $\mathrm{ml}$, and $10 \%$ fetal calf serum (Life Technologies).

\section{DC preparation and treatment}

All human specimens were obtained under informed consent, as approved by the University of Maryland Baltimore Institutional Review Board. Monocyte-derived DCs were generated as described previously (17), with minor modifications. Briefly, human peripheral blood mononuclear cells were isolated, from three independent normal healthy donors, by Ficoll-Hypaque density gradient centrifugation and were enriched for $\mathrm{CD} 14^{+}$monocytes by negative selection with a cocktail of monoclonal antibodies from StemCell Technologies (Vancouver, British Columbia, Canada), according to the instructions of the manufacturer. Typically, greater than $80 \%$ of the cells were $\mathrm{CD} 14^{+}$after enrichment (data not shown). The isolated monocytes were allowed to adhere to plastic by plating $10^{6}$ cells per/ml in RPMI 1640 medium for $2 \mathrm{~h}$. Adherent monocytes were washed with RPMI 1640 medium and were then cultured for 6 days at $10^{6}$ cells per/ $\mathrm{ml}$ in DC culture medium supplemented with $50 \mathrm{ng}$ of recombinant GM-CSF (rGM-CSF, R\&D Systems, Minneapolis, Minn.) per $\mathrm{ml}$ and 1,000 U of recombinant IL-4 (rIL-4; R\&D Systems, Minneapolis, Minn.) per ml.

After 6 days in culture, MDDCs were pulsed with either 5 $\mu \mathrm{g} / \mathrm{ml}$ of HIV-VLPs or $1 \mu \mathrm{g} / \mathrm{ml}$ of LPS for 4 and 8 hours, for gene microarray analysis, and for 16 hours for maturation and activation phenotype analysis.

\section{Analysis of DC phenotype}

DCs were incubated for $30 \mathrm{~min}$ at $4{ }^{\circ} \mathrm{C}$ with murine monoclonal antibodies specific for CD80, CD83, CD86, and HLA-DR (BD Pharmingen, San Diego, CA), washed and then fixed with $2 \%$ paraformaldehyde for analysis with a FACScalibur flow cytometer (BD Pharmingen). Data analysis was carried out with FlowJo software (Tree Star Inc., San Carlos, CA). The fraction of MDDCs that responded by upregulation of activation markers on the cell surface was calculated by overlaying the histograms of treated and untreated MDDCs and Overton subtraction of the curves.

\section{RNA preparation and microarray hybridization}

DCs were harvested, washed twice in PBS and lysed in 350 ul RLT buffer with fresh addition of 2-Mercaptoethanol per each well of the 6-well plate. Total RNA was isolated using RNeasy minikits (Qiagen), according to the manufacturer's protocol, and RNA quality and quantity was estimated by Agilent Bioanlayzer (Agilent Technologies, Palo Alto, CA) and NonoDrop. Amplified antisense RNA (aRNA) was obtained from total RNA $(0.5-3 \mu \mathrm{g})$ via two round of in vitro transcription, according the protocol previously described by us [26]. 6 ug of amplified test samples aRNA were labeled with Cy5 (Amersham) while the same amount of reference sample (pooled normal 


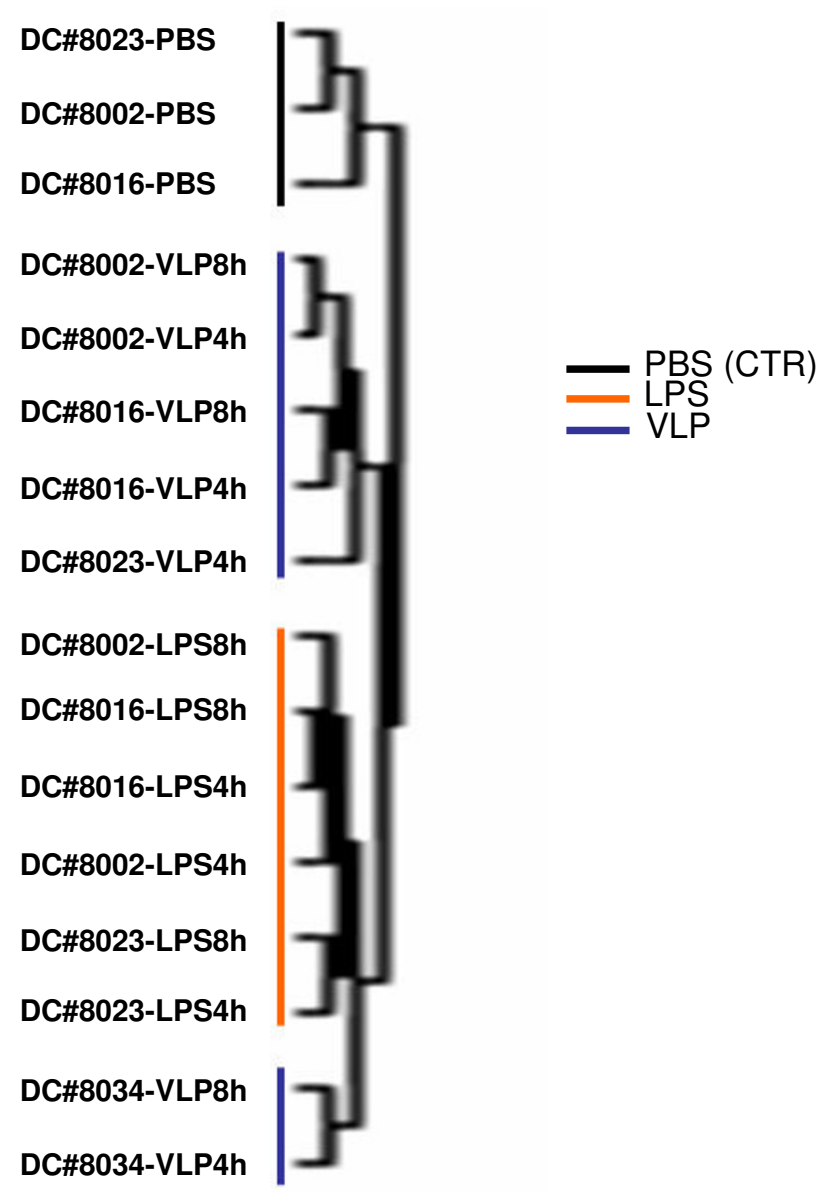

Figure 2

Unsupervised hierarchical clustering of all filtered

data. The clusterogram represents 3,119 genes obtained by Eisen hierarchical clustering of the complete I7K dataset filtered for genes that are expressed in a minimum of $80 \%$ of the samples 4 and $8 \mathrm{~h}$ after HIV-VLPs or LPS stimulation. The PBS treatments was evaluated after $8 \mathrm{~h}$ of stimulation. The clustering is defined by the dendrogram and each treatment/ time point is represented by a single branch.

donor PBMCs) was labeled with Cy3. Test-reference sample pairs were mixed and co-hybridized to $17 \mathrm{~K}$ cDNA microarrays [27].

\section{Microarrays and statistical analyses}

Hybridized arrays were scanned at $10-\mu \mathrm{m}$ resolution on a GenePix 4000 scanner (Axon Instruments) at variable PMT voltage to obtain maximal signal intensities with less than $1 \%$ probe saturation. Resulting jpeg and data files were deposited at microarray data base (mAdb) http://nci array.nci.nih.gov and retrieved after median centered, filtering of intensity (>300) and spot elimination (bad and no signal). Data were further analyzed using Cluster and TreeView software [27] and Partek Pro software (Partek).
Subsequent low-stringency filtering (80\% gene presence across all experiments and at least one experiment with ratio fold change >3), 3,119 genes were selected for further analysis. Hierarchical cluster analysis was conducted on these genes according to Eisen et al. [28]; differential expressed genes were visualized by Treeview and displayed according to the central method [29].

\section{Results \\ Baculovirus-HIV-VLP induces a maturation phenotype of DCs}

Immature MDDCs were obtained from three independent donors and, after 6 days of culture in IL-4- and GM-CSFenrichment medium, were incubated with $5 \mu \mathrm{g} / \mathrm{ml}$ of baculovirus-expressed HIV-VLPs or $1 \mu \mathrm{g} / \mathrm{ml}$ of LPS. In parallel, control MDDCs were loaded with PBS. After a 16 hrinduction, the expression of surface maturation/activation markers, such as CD80, CD83, CD86 and HLA-DR, was examined. The expression of all the four markers was upregulated by treatment with HIV-VLPs, compared to PBS (Fig. 1). The level of cytokines involved in the Th1/ Th2 polarization was assessed in the supernatant of MDDCs loaded with HIV-VLPs or LPS. In particular, the TNF- $\alpha$, IL-12 p70, IL-10 were produced at higher levels in HIV-VLP-loaded MDDCs compared to LPS-loaded MDDCs (data not shown).

These results indicate that baculovirus HIV-VLPs induce a specific MDDC maturation pathway, distinct from the one induced by the LPS.

\section{Pattern of MDDCs response to HIV-VLPs}

Gene expression profiles were generated from treated and control MDDC harvested 4 and 8 hrs after stimulation. These time points were selected to evaluate a possible biphasic response, as described for LPS-induced DCs and mononuclear phagocytes (MPs) [23,25]. Amplified antisense RNA (aRNA) was obtained from total RNA extracts [26] and hybridized to a custom-made 17,000 (17K)clone cDNA microarray chip enriched with genes relevant to immune function. Stringent filtering were further applied to eliminate genes with missing value in $>20 \%$ of all the experiments and $>3$ fold change in at least one experiment. The remaining 3,119 genes were thus used for statistic analysis.

Unsupervised cluster analysis obtained on MDDCs stimulated for 4 and $8 \mathrm{hr}$ with HIV-VLPs or LPS shows the segregation of the untreated (PBS) and the treated (HIV-VLPs or LPS) MDDCs in two independent clusters. However, within the treated MDDCs cluster, the samples subclustered according to the treatment (HIV-VLPs vs LPS), with the exception of a single HIV-VLP-treated sample which formed an independent cluster closer to the LPS-treated sample, indicating the induction of two distinct transcrip- 


\section{Upregulation}

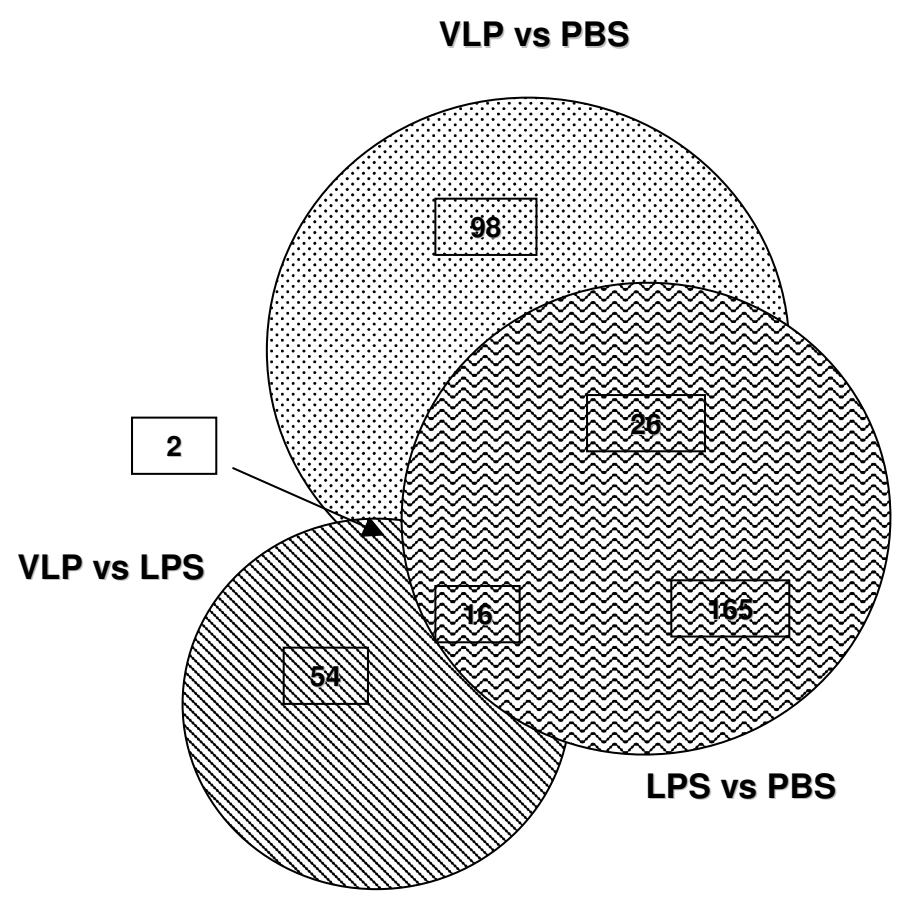

\section{Downregulation}

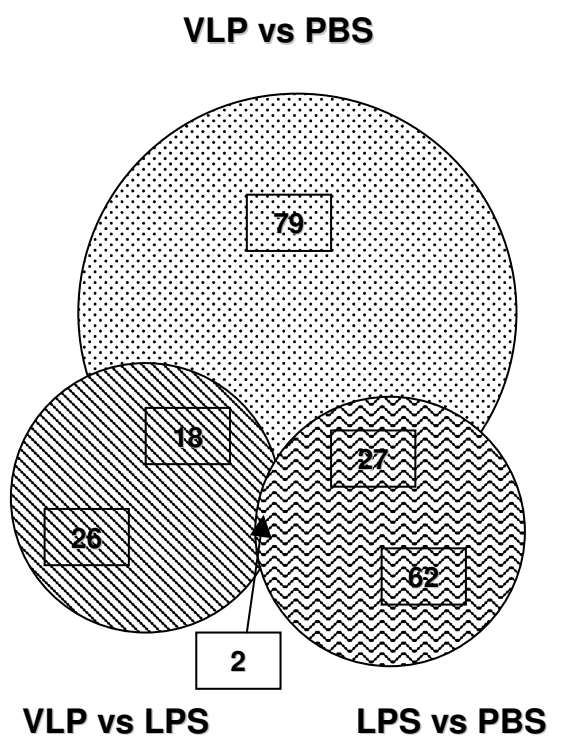

\section{Figure 3}

Pattern of gene expression in human monocyte-derived DCs. Regulated genes by HIV-VLPs or LPS treatment in MDDCs, showing at least a 2-fold modulation (up or downregulation), have been evaluated. Each circle represents the whole set of genes identified in the indicated comparisons, based on the 2-fold modulation parameter. Numbers in overlapping regions represent common regulated genes. Numbers in non-overlapping regions represent unique regulated genes. Circles are drawn in arbitrary scale.

tion machinery. Furthermore, while the HIV-VLP-treated MDDCs clustered according to the donor, the LPS-treated MDDCs clustered preferentially according to the treatment duration ( 4 or $8 \mathrm{hr}$ ) of stimulation (Fig. 2). This would suggest an individual donor susceptibility to HIVVLP-treatment and a possible delayed transcription or secondary response to LPS treatment.

\section{Gene expression changes induced in MDDCs by HIV-VLP treatment}

The differential gene expression in HIV-VLP-treated MDDCs, compared to either LPS- or PBS-treated MDDCs, was considered statistically significant only when supported by a $\mathrm{p}<0.005$.

Treatment-induced changes in gene profiling were analyzed using student $t$ test, based on simple two-treatment comparison or one versus a combined two-treatment comparison. Considering only genes showing at least a 2fold modulation (increase or reduction) in the transcrip- tional levels, it has been possible to identify unique and common genes in the profile induced by the different treatments. In particular, the HIV-VLP treatment, induced the upregulation of 140 and 72 genes as well as the downregulation of 108 and 46 genes, compared to PBS and LPS respectively. A sub-set of upregulated and downregulated genes are specific to the HIV-VLP treatment (Fig. 3), indicating that, besides transcriptional patterns shared with the LPS treatment, HIV-VLPs induce a specific reprogramming of the MDDCs transcriptional profile.

Visualization of the gene expression among different treatments revealed a transcriptional profile pattern in HIV-VLP-induced MDDCs distinct from either PBS or LPS ( $4 \mathrm{hr}$ and $8 \mathrm{hr}$ ) induction (Fig. 4A). Furthermore, clustering analysis performed based on 217 genes selectively expressed ( $\mathrm{p}<0.005)$ in HIV-VLP induced MDDCs, compared to LPS treatment, confirmed a distinct transcriptional profiles signature according to the treatment, regardless of the length of stimulation (Fig. 4B). 


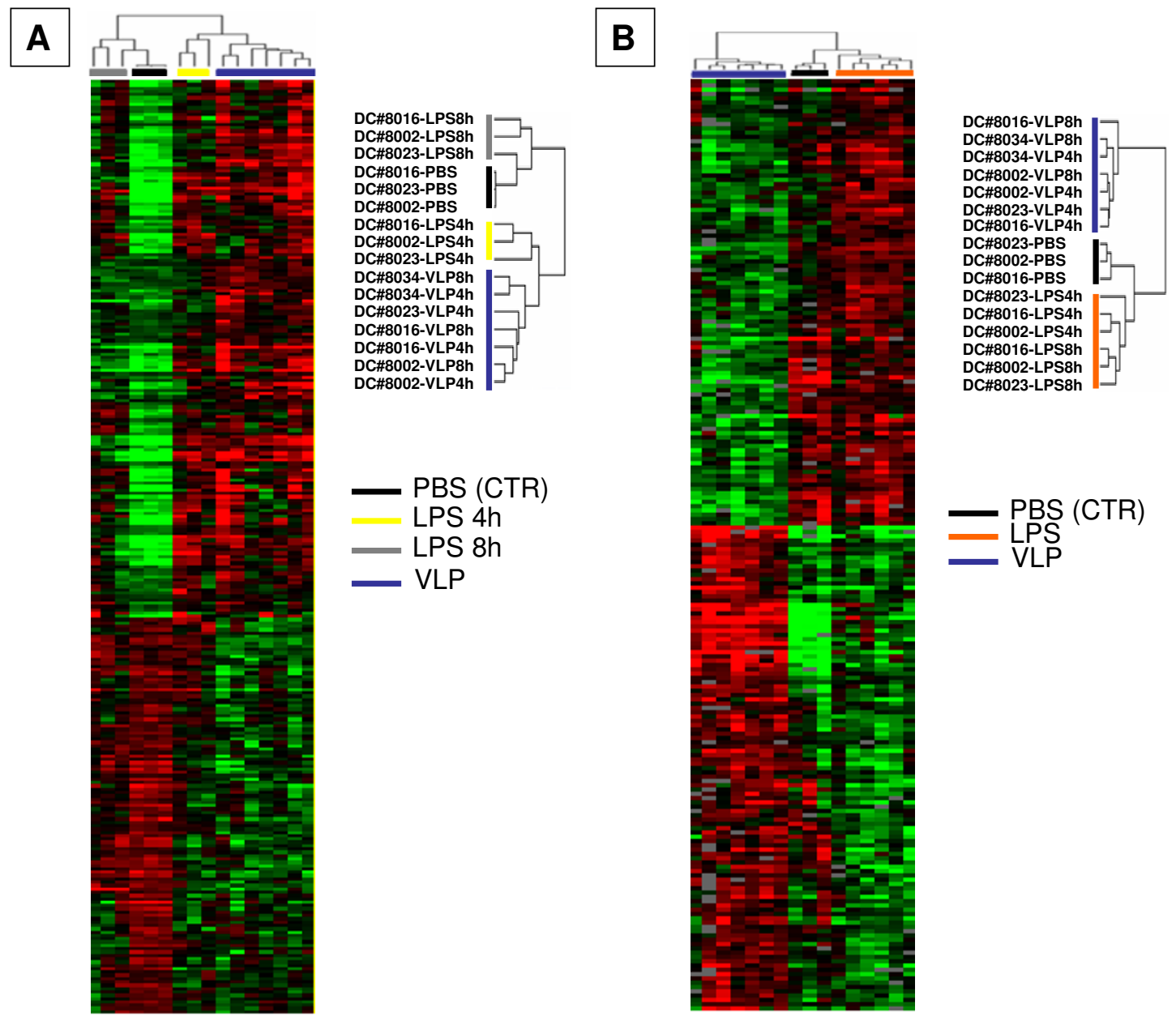

\section{Figure 4}

Supervised hierarchical clustering of genes differentially expressed in HIV-VLP-treated MDDCs. The clusterograms represent an Eisen hierarchical clustering of the $28 \mathrm{I}$ genes differentially expressed $(p<0.005)$ in HIV-VLPs-treated MDDCs, compared to PBS treatment (A), and of 217 genes differentially expressed $(p<0.005)$ in HIV-VLPs-treated MDDCs, compared to LPS treatment $(\mathbf{B})$. The clustering is defined by the dendrogram on the top and on the side of the clusterogram.

Pathways modulation in MDDCs in response to HIV-VLPs Gene expression changes in response to stimuli are generally pathways directed. In order to analyse pathways modulated in HIV-VLPs induced MDDCs, we dissected genes according to cluster nodes derived on the basis of expression similarity. Supervised cluster analysis based on the 3,119 genes were further analyzed according to pattern recognition. Genes uniquely upregulated in MDDCs by HIV-VLPs only or by HIV-VLPs and LPS (either at 4 h or 8 $\mathrm{h}$ post-induction) are indicated in Fig. 5A and 5B respectively. Similarly, nodes were identified including genes down-regulated by HIV-VLPs only or by HIV-VLPs and LPS at $4 \mathrm{~h}$ post-induction (Fig. 5C top and bottom, respectively). Most of the genes present in these nodes are strictly associated to the functional and morphological changes characterizing the MDDCs maturation and activation process.

In this regard, the MDDCs transcriptional profile was analyzed on the basis of the cellular pathways modulated by the HIV-VLP-treatment, compared to either PBS or LPS treatment. In respect to the main focus of this study, only the pathways involved in the MDDCs-activation by HIVVLPs have been evaluated in more detail. These can be divided into main super-families concerning the cell replication/death, the transcriptional control, the phagocytosis and pathogen recognition, the immunological function of dendritic cells, the migration and the control of the inflammatory responses (Table I). 

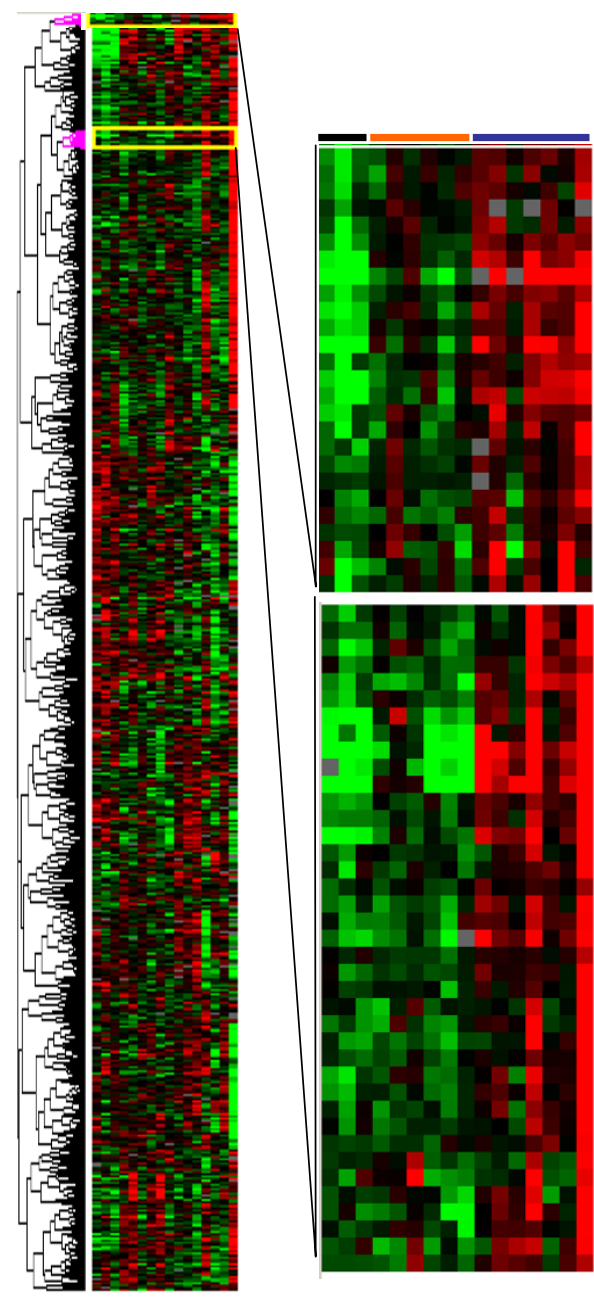

MEF2A - MADS box transcription enhancer factor 2

NFE2L2 - Nuclear factor-like 2
DC-UbP - Dendritic cell-derived ubiquitin-like protein

DGMH - Diasplgglycerol kinase
DTGS2 - Prostaglandin-endoperoxidase synthase 2

IL8 - Interleukin 8
ARRB1 - Arrestin beta 1

ARRB1 - Arrestin beta 1
BTG3 - BTG family member 3

SOSTM1 - Sequestosome 1

HLA-DOA - MHC class II
HSPC121 - Butyrate-induced transcript

TADA3L - Transcriptional adaptor 3

MST4 - Mst3 and SOK1-related kinase

B4GALT5 - UDP-Gal:betaGIcNAc bea 1.4-galactosyltransferase
MTHFD2 - NAD-dependent methylenetetrahydrofolate deydrogenase

SGTB - Small glutamine-rich tetratricopeptide repeat

PRKX - Protein Kinase, $X$-linked

N4BP1 1 - Nedd4 binding protein 1

PELI1 - Pellino homolog 1
SC4MOL - Sterol-C4-methyl oxidase-like

SC4MOL - Sterol-C4-methyl oxidase-like
BAG3 - BCL2-associated athanogene 3

KCNK10 - Potassium channel, subfamily K, member 10

PBEF1 - Pre-B-cell colony enhancing factor 1
PBEF1 - Pre-B-cell colony enhancing factor 1

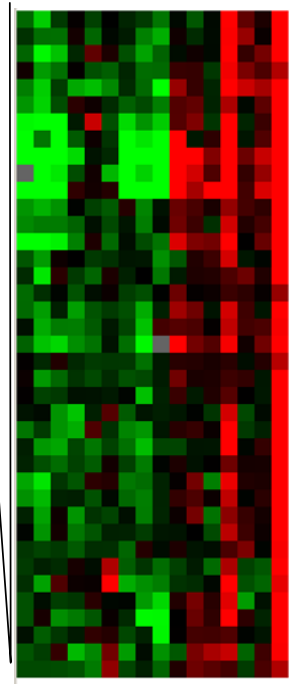

Similar to tripartite motif-containing 16 ; estrogen-responsive $B$ box protein

SOX4-SRY (sex determining region Y) - box 4

ADM - Adrenomedullin
CIR - CBF1 interacting corepressor

GEM - GTP binding protein

TNFSF9 - 4-1BB ligand

IL6-Interleukin 6

CXCL3 - GRO3,

CXCL3 - GRO3, MIP2 beta

IL1A - Interleukin 1 alpha

SOSTM1 - Sequestosome 1
ARFGAA3 $-A D P$-ribosylation factor GTPase activating protein 3

NFKBIA - IKB alpha

DTX2-Deltex homolog 2
SLC11A2 - Solute carrier family 11

H3F3B - H3 Histone, family $3 B$

MAPK6 - mitogen-activated protein kinase 6

BAI3 - Brain-specific angiogenesis inhibitor 3

LOC440309

CSF2 - Colony stimulating factor 2 (granulocyte-macrophage)

NR3C1 - Nuclear receptor subfamily 3

HAZ - Tyrosine 3-monooxygenase

TFPI2 - Tissue factor pathway inhibitor 2

PTS - 6-pyruvoyltetrahydropterin synthas
STK17A-Serine/threonine kinase 17 a

TBCA - Tubulin-specific chaperon a
TB

TBCA - Tubulin-specific chaperon a
C8orf1 - Chromosome 8 open reading frame 1
C8orf1 - Chromosome 8 open reading frame 1

RHCG - Rhesus blood group, C gly
CA11 - Carbonic anhydrase XI

RPS15A - Ribosomal protein S15a

TKTL1 - Transketolase-like 1

RRPC1 - Transient receptor potential cation channel, subfamily $C$

DASPG

AREG - Dual specificity phosphatase 6
ARregulin

\section{Figure 5}

Supervised hierarchical clustering of genes upregulated by HIV-VLPs in MDDCs. 3, I 19 genes included in this analysis were filtered upon the criteria of showing less than $20 \%$ missing data and a minimum of 3 -fold modulation in expression. The expanded section shows nodes including genes upregulated by HIV-VLPs. Individual genes are indicated on the right.

The MDDCs differentiation process induced by HIV-VLPs, in fact, results in the reduced transcriptional levels of genes associated with phagocytosis and pathogen recognition. In parallel, an activation of genes associated with antigen presentation functions is observed. A set of cytoskeletal genes that may potentially mediate shape change and migratory behavior of activated DCs is also observed. The increase in the expression of immune cytokines, chemokines, and receptors contribute to the recruitment of monocytes, DCs, and macrophages to the site of infection. Moreover, they modulate both innate and adaptive immune response, including the polarization of Th cells, and the down-regulation of the inflammatory response, which may significantly interfere with the immune response. The induction of signaling genes and transcription factors may be involved in preparing the DC to be receptive to regulatory signals in the lymphatics and lymph nodes.

Finally, genes involved in the cell replication and apoptosis are modulated in their transcriptional levels, in agreement with the observation that mature DC undergo growth arrest, terminal differentiation and die by apoptosis 8-9 days after activation in vivo.

It is not unexpected that many pathways share same genes with intra-cellular functions involved in several biological outcomes. The majority (60\%) of the pathways specifically modulated in the MDDCs by the HIV-VLPs treatment result from the comparison with the PBS treatment; the remaining $40 \%$, instead, derives from the comparison with both PBS and LPS treatments. 
Table I: Pathways involved in the HIV-VLPs-activated MDDCs. The pathways are derived from the BioCarta through the Cancer Genome Anatomy Project at http:// ggap.nci.nih.gov/Pathways/BioCarta Pathways. Genes with at least a 2-fold modulation (up or downregulation) have been taken into consideration. Upregulated genes in bold and underline; Downregulated genes in plain text.

\begin{tabular}{|c|c|c|c|c|c|c|c|c|}
\hline Pathways & HIV-VLP vs PBS & HIV-VLP vs LPS & Pathways & HIV-VLP vs PBS & HIV-VLP vs LPS & Pathways & HIV-VLP vs PBS & HIV-VLP vs LPS \\
\hline Cell cycle, death & & & Transcription & & & Immunology/Signaling & & \\
\hline $\begin{array}{l}\text { Cadmium induces DNA } \\
\text { synthesis and proliferation in } \\
\text { macrophages }\end{array}$ & $\frac{\text { NFKBI }}{\text { MAPKI }}$ & $\underline{\mathrm{TNF}}$ & $\begin{array}{l}\text { Acetylation and Deacetylation } \\
\text { of RelA in The Nucleus }\end{array}$ & $\frac{\text { NFKBI }}{\text { FADD }}$ & $\frac{\text { NFKBIA }}{\frac{\text { TNF }}{\text { FADD }}}$ & AKT Signaling Pathway & $\begin{array}{l}\frac{\text { FOXO3A }}{\text { NFKBI }} \\
\text { CASP9 } \\
\text { YWHAH }\end{array}$ & \\
\hline Caspase Cascade in Apoptosis & $\begin{array}{l}\text { BIRC3 } \\
\text { CASP7 } \\
\text { CASP2 } \\
\text { CASP9 } \\
\text { PARPI }\end{array}$ & & $\begin{array}{l}\text { Activation of PKC through G } \\
\text { protein coupled receptor }\end{array}$ & $\begin{array}{l}\text { GNAQ } \\
\text { NFKBI }\end{array}$ & & $\begin{array}{l}\text { B Lymphocyte Cell Surface } \\
\text { Molecules }\end{array}$ & $\frac{\text { CD40 }}{\text { FCGR2A }}$ & NFKBIA \\
\hline Free Radical Induced Apoptosis & $\begin{array}{c}\frac{\text { GSR }}{\text { IL8 }} \\
\text { NFKBI }\end{array}$ & & $\begin{array}{l}\text { Chaperones modulate } \\
\text { interferon Signaling Pathway }\end{array}$ & $\frac{\text { DNAJA3 }}{\text { IFNG }}$ & $\frac{\underline{\text { IFNG }}}{\frac{\text { LIN7A }}{\text { NFKBIA }}} \frac{\text { RBI }}{\underline{\text { TNF }}}$ & CD40L Signaling Pathway & $\frac{\frac{\text { CD40 }}{\text { DUSPI }}}{\frac{\text { TNFAIP3 }}{\text { TRAF6 }}}$ & $\begin{array}{l}\frac{\text { DUSPI }}{\text { MAP3KI }} \\
\text { NFKBIA } \\
\text { TNFAIP3 }\end{array}$ \\
\hline $\begin{array}{l}\text { Induction of apoptosis through } \\
\text { DR3 and DR4/5 Death } \\
\text { Receptors }\end{array}$ & 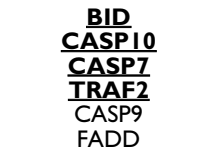 & & $\begin{array}{l}\text { Double Stranded RNA } \\
\text { Induced Gene Expression }\end{array}$ & NFKBI & & $\begin{array}{l}C T L \text { mediated immune } \\
\text { response against target cells }\end{array}$ & $\begin{array}{l}\text { ICAMI } \\
\text { B2M } \\
\text { LTBR } \\
\text { ITGAL }\end{array}$ & \\
\hline $\begin{array}{l}\text { Neuropeptides VIP and PACAP } \\
\text { inhibit the apoptosis of activated } \\
\text { T cells }\end{array}$ & $\frac{\frac{\text { GNAQ }}{\text { NFKBI }}}{\frac{\text { PRKARIB }}{\text { CAMKI }}}$ & & $\begin{array}{l}\text { Human Cytomegalovirus and } \\
\text { Map Kinase Pathways }\end{array}$ & 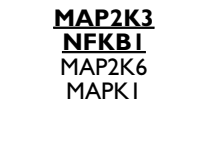 & & $\begin{array}{l}\text { fMLP induced chemokine } \\
\text { gene expression in HMC-I } \\
\text { cells }\end{array}$ & $\begin{array}{l}\frac{\text { FPRI }}{\text { MAP2K2 }} \\
\text { NFKBI } \\
\text { CAMK1 } \\
\text { MAP2K6 } \\
\text { MAPKII }\end{array}$ & \\
\hline $\begin{array}{l}\text { Regulation of BAD } \\
\text { phosphorylation }\end{array}$ & $\begin{array}{c}\frac{\text { BCL2LI }}{\text { IGFIR }} \\
\text { PRKARIB } \\
\text { MAPKI } \\
\text { RPS6KAI } \\
\text { YWHAH }\end{array}$ & & $\begin{array}{l}\text { NFkB activation by } \\
\text { Nontypeable Hemophilus } \\
\text { influenzae }\end{array}$ & $\begin{array}{l}\frac{\text { DUSPI }}{\text { EP300 }} \\
\text { MAP2K3 } \\
\text { NFKBI } \\
\text { NR3CI } \\
\text { SMAD4 } \\
\text { MAP2K6 } \\
\text { SMAD3 } \\
\text { TGFBR2 }\end{array}$ & $\begin{array}{c}\frac{\text { DUSPI }}{\text { IL8 }} \\
\text { NFKBIA } \\
\frac{\text { SMAD4 }}{\text { SMADA }} \\
\frac{\text { TNKF }}{\text { IKBKB }} \\
\text { MAP2K6 } \\
\text { SMAD3 }\end{array}$ & $\begin{array}{l}\text { Monocyte and its Surface } \\
\text { Molecules }\end{array}$ & $\begin{array}{c}\frac{\text { ICAMI }}{\frac{\text { ICAM2 }}{\text { CD44 }}} \\
\frac{\text { LTBR }}{\text { LTELE }} \\
\text { SED83 } \\
\text { HLA-DOA } \\
\text { ITGAL } \\
\text { PECAMI }\end{array}$ & \\
\hline $\begin{array}{l}\text { Role of Mitochondria in } \\
\text { Apoptotic Signaling }\end{array}$ & $\begin{array}{c}\frac{\text { BCL2LI }}{\text { BID }} \\
\frac{\text { BIRC3 }}{\text { CASP7 }} \\
\frac{\text { ENDOG }}{\text { CASP9 }} \\
\text { PDCD8 }\end{array}$ & & NF-kB Signaling Pathway & $\frac{\frac{\text { IRAKI }}{\text { NFKBI }}}{\frac{\text { TNFAIP3 }}{\text { TRAF6 }}} \frac{\text { FADD }}{\text { FADE }}$ & $\begin{array}{l}\frac{\text { ILIA }}{\text { MAP3KI }} \\
\frac{\text { NFKBIA }}{\text { TNF }} \\
\frac{\text { TNFAIP3 }}{\text { FADD }}\end{array}$ & $\begin{array}{l}\text { T Cytotoxic Cell Surface } \\
\text { Molecules }\end{array}$ & $\begin{array}{c}\frac{\text { CD8A }}{\frac{\text { ICAMI }}{\text { LTBR }}} \\
\text { CD2 ITGAL } \\
\text { PTPRC }\end{array}$ & \\
\hline SODD/TNFRI Signaling Pathway & $\frac{\frac{\text { BIRC3 }}{\text { TRAAF2 }}}{\text { FADD }}$ & & $\begin{array}{l}\text { Signal transduction through } \\
\text { ILIR }\end{array}$ & $\frac{\frac{\text { ILIB }}{\text { MAP2K3 }}}{\frac{\text { NFKBI }}{\text { TRAF6 }}}$ & $\frac{\frac{\text { ILIA }}{\text { MAP3KI }}}{\text { NFKBIA }}$ & $\begin{array}{l}\text { T Helper Cell Surface } \\
\text { Molecules }\end{array}$ & $\begin{array}{l}\frac{\text { ICAMI }}{\text { LTBR }} \\
\text { CD2 } \\
\text { CD4 } \\
\text { ITGAL } \\
\text { PTPRC }\end{array}$ & \\
\hline $\begin{array}{l}\text { Stress Induction of HSP } \\
\text { Regulation }\end{array}$ & $\begin{array}{l}\text { CASP9 } \\
\text { MAPKAPK3 }\end{array}$ & $\begin{array}{l}\frac{\text { ILIA }}{\text { TNF }} \\
\text { CASP9 } \\
\text { CYCI }\end{array}$ & TNFRI Signaling Pathway & $\begin{array}{l}\frac{\text { PAK2 }}{\text { TRAF2 }} \\
\text { CASP2 } \\
\text { FADD } \\
\text { PARPI }\end{array}$ & & $\begin{array}{l}\text { The 4-IBB-dependent } \\
\text { immune response }\end{array}$ & $\frac{\frac{\text { IFNG }}{\text { NFKB1 }}}{\text { INFSF9 }}$ & \\
\hline
\end{tabular}


Table I: Pathways involved in the HIV-VLPs-activated MDDCs. The pathways are derived from the BioCarta through the Cancer Genome Anatomy Project at http:// cgap.nci.nih.gov/Pathways/BioCarta Pathways. Genes with at least a 2-fold modulation (up or downregulation) have been taken into consideration. Upregulated genes in bold and underline; Downregulated genes in plain text. (Continued)

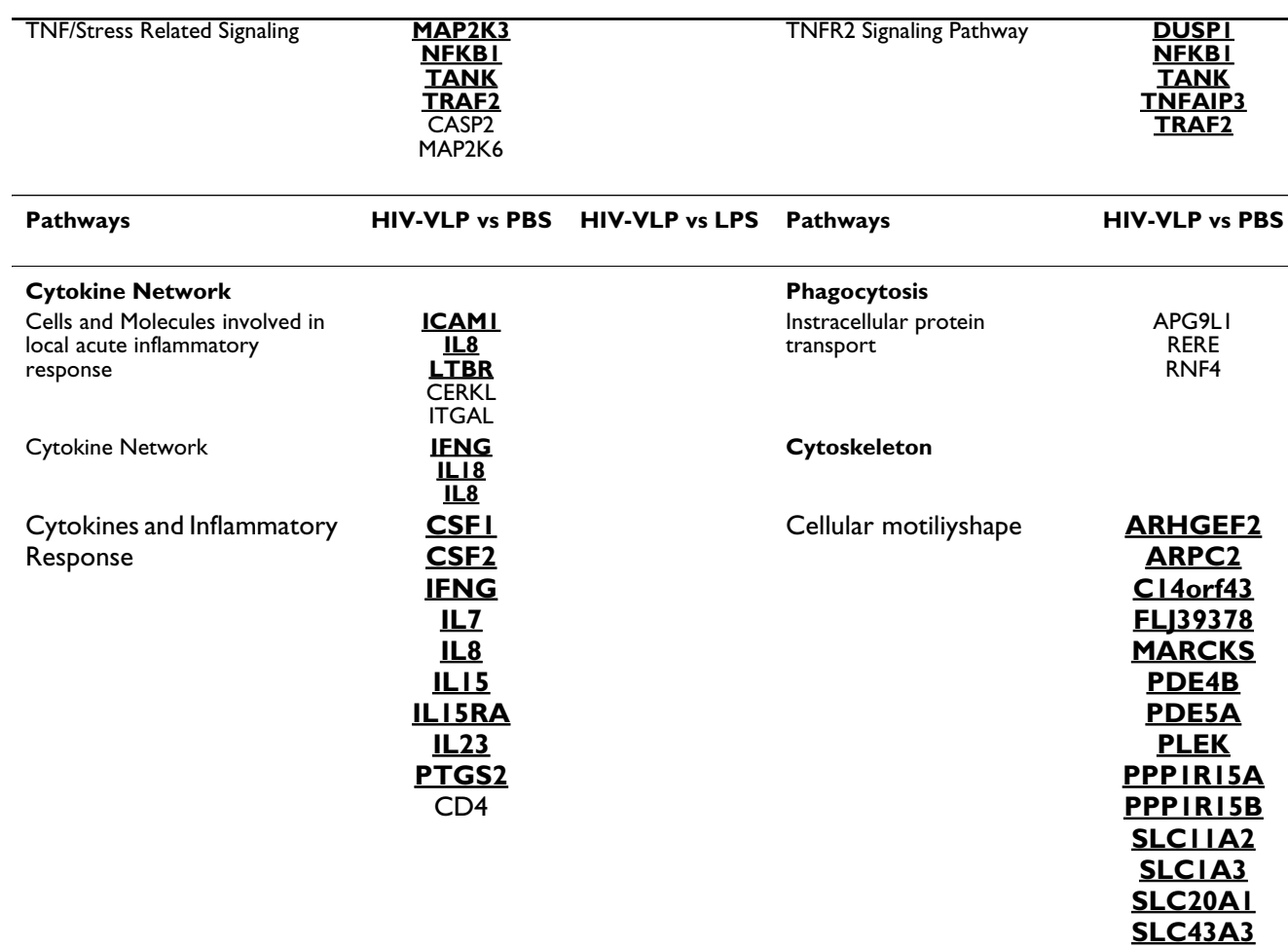

$\begin{array}{lr}\text { IL I7 Signaling Pathway } & \frac{\text { CD8A }}{\underline{\text { IL8 }}} \\ \frac{\text { CD58 }}{\text { CD2 }} \\ \text { CD4 } \\ \text { Th1/Th2 Differentiation } & \underline{\underline{\text { ILI8 } 8}} \\ & \underline{\underline{L L / 8 R}}\end{array}$


Table 2: Functional categories of genes differentially upregulated in HIV-VLPs-induced MDDCs. (+) I.5-fold upregulation; (++) 2-5-fold upregulation; (+++) $>5$-fold upregulation.

\begin{tabular}{|c|c|c|c|c|c|}
\hline Pathway & HIV-VLP vs PBS & HIV-VLP vs LPS & Pathway & HIV-VLP vs PBS & HIV-VLP vs LPS \\
\hline Cell cycle, death & & & Chemokine/Imn & & \\
\hline TNF & ++ & + & Innate response & & \\
\hline $\mathrm{BIRC} 3$ & ++ & & IL8 & +++ & ++ \\
\hline CASP7 & + & & CXCLI & ++ & ++ \\
\hline BID & ++ & & $\mathrm{ILIa}$ & ++ & ++ \\
\hline PAK2 & ++ & & ILIb & ++ & \\
\hline TRAF2 & ++ & & IL6 & ++ & \\
\hline BCL2LI & + & & CCL4 & ++ & \\
\hline IGFIR & ++ & & IFNG & & + \\
\hline TNFAIP3 & ++ & & PTGER4 & & \\
\hline TANK & ++ & & Adaptive response & & \\
\hline PSENI & + & & $\mathrm{EB} 12$ & ++ & \\
\hline TNFRSFIB & +++ & + & ICAMI & ++ & \\
\hline Transcription & & & B2M & + & \\
\hline NFKBI & + & & Receptors & & \\
\hline NFKBIA & & ++ & ILI5RA & ++ & \\
\hline IRAKI & + & & ILI8RI & ++ & \\
\hline MAP3KI & & + & IL23A & ++ & \\
\hline JUNB & + & & IL2RB & ++ & \\
\hline Signaling & & & FCGR2A & ++ & \\
\hline MAP2K7IP2 & + & & IL7R & ++ & \\
\hline DUSPI & ++ & + & CD83 & ++ & \\
\hline MAP2K3 & + & & Growth Factors & & \\
\hline PAK2 & ++ & & CSFI & ++ & \\
\hline RBI & & + & CSF2 & + & \\
\hline FOXO3A & + & & $\begin{array}{l}\text { Migration and } \\
\text { Homeostasis }\end{array}$ & & \\
\hline FYN & & + & CCR7 & + & \\
\hline GNAQ & + & & FPRI & ++ & \\
\hline MEF2A & + & & SELE & ++ & \\
\hline \multirow[t]{6}{*}{ RAPGEF2 } & & + & CD44 & ++ & \\
\hline & & & LTBR & + & \\
\hline & & & $\begin{array}{l}\text { T-cell activation/ } \\
\text { polarization }\end{array}$ & & \\
\hline & & & CD40 & ++ & \\
\hline & & & TNFSF9 & & + \\
\hline & & & ILI8 & + & \\
\hline
\end{tabular}

Functional implementation of activated genes in MDDCs in response to HIV-VLPs

The effects of the HIV-VLP treatment on MDDCs, compared to the PBS and LPS treatments, has been analyzed also considering the individual genes showing increased transcriptional levels. The presumed biological implication of selected genes involved in the specific functions of Dendritic Cells as professional APCs, has been evaluated in more detail according to their function (Table II).

STAT2 is activated upon the binding of type-I IFN, the major component of the innate immune system, to its receptor and participates to the formation of interferonstimulated gene factor 3 (ISGF3) complex, composed of STAT1, STAT2, and IFN regulatory factor 9, which promotes serial synthesis of selected proteins that inhibit viral replication $[30,31]$.
Macrophage and Granulocyte-Macrophage Colony Stimulating Factor, CSF1 and CSF2, represent the main factors involved in proliferation and differentiation of myeloid lineage progenitor cells [32-35]. They may contribute to an increased production and recruitment of monocytes, DCs, and macrophages to the site of infection.

Formyl Peptide Receptor (FPR) is responsible for the DC chemoattraction to the Gram-negative bacteria Formyl peptide N-formyl-Met-Leu-Phe (fMLP) [35] and to additional pathogen-derived peptides, including HIV $[36,37]$. E-Selectin (SELE) and Chemokine (C-C motif) receptor 7 (CCR7) are selectively expressed on mature DCs, following encounter with pathogens. They favor the interaction with the endothelial cells as well as the migration from peripheral tissues to the $\mathrm{T}$ cell areas of secondary lymphoid organs, where they produce regulatory cytokines 

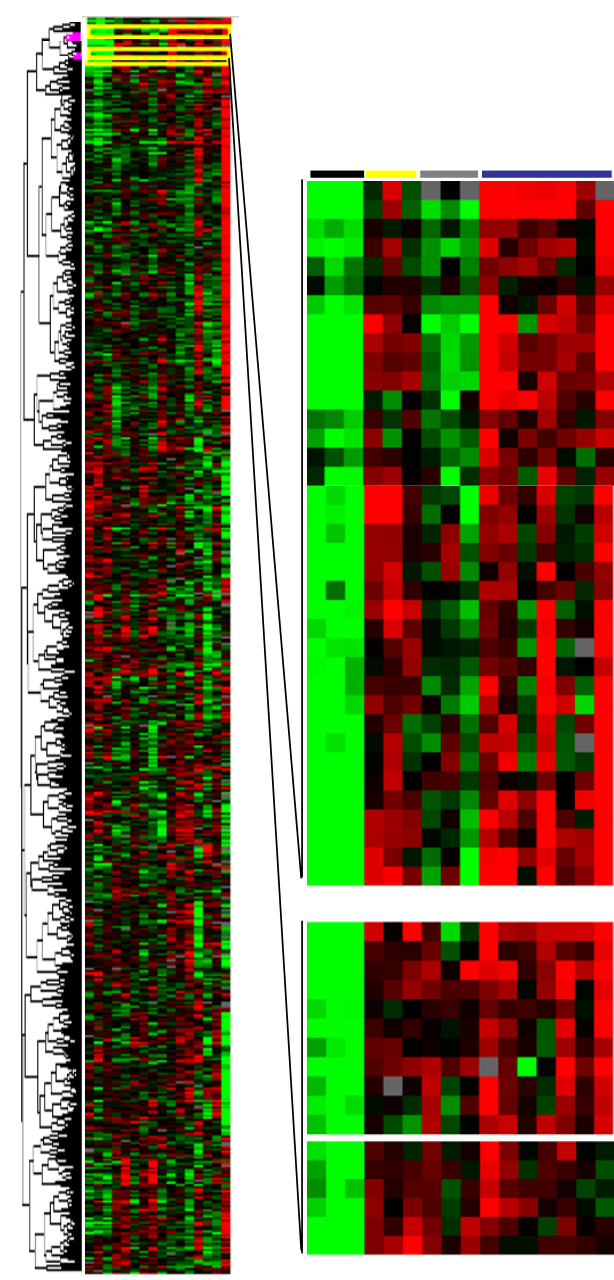

Tumor Necrosis Facto 2 TNF - Tumor necrosis Factor F3 - Coagulation factor III CCRL2 - Chemokine receptor 2 PALM2-AKAP2 - Paralemmin 2 IL23A - Interleukin 23a ARPC2 - Actin related protein 2 BCL2A1 - Bcl-2 related protein BCL2A1 - BCL2-related protein A1 NFKBIZ - Nuclear factor

RASGRP1- RAS guanyl releasing protein 1 WTAP - Wilms tumor 1 associate protein

ARHGAP4 - Rho GTPase activating protein 4

CSF1 - colony stimulating factor 1 (macrophage)

EHD1 - EH-domain containing 1

THD1 - EH-domain contaning 1

NINJ1 - Ninjurin 1

CCL5 - Chemokine ligand 5

CSF1 - Colony stimulating factor 1 (macrophage)

HSGT1 - Suppressor of S. Cerevisiae

ASCL1 - Acyl-CoA synthetase long-chain family member 1

LEK - Pleckstrin

KLRC3 - Killer cell lectin-like receptor subfamily C, member 2

PDE5A - Phosphodiesterase 5A

SDC4 - Syndecan-4

TGAV - integrin,
CAM1 - CD54

CAM1 - CD54

USP 5 - dual specificity phosphatase 5

Putative lymphocyte GO/G1 switch gene

CCL3 - LD78 beta

CL3 - Chemokine ligand 3

CCL4 - MIP-1 beta

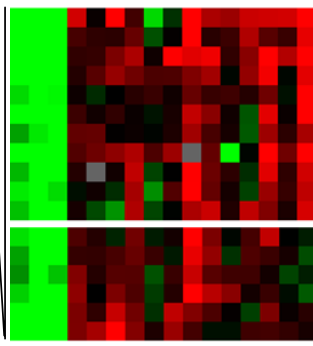

CCL20 - Chemokine ligand 20

NFAIP3 - Tumor necrosis factor, alpha-induced protein 3

SOD2 - Superoxidase dismutase 2

CREM - CAMP responsive element modulator

UREM - cAMP responsive elemen

CD44 - Pgp-1 extracellular matrix receptor

SGPP2 - Sphingosine-1-phosphatase

TNFAIP3 - Tumor necrosis factor, alpha-induced protein

TGA6 - integrin alpha 6

DEAF1 - Deformed epidermal autoregulatory factor 1

BIRC3 - Baculovirus IAP repeat-containing 3

EMA5A - Sema domain, seven thromspondin repeats

PTPLB - Protein tyrosine phosphatase-like

ontaining 2

KYNU - Kynureninase

\section{Figure 6}

Supervised hierarchical clustering of genes upregulated by HIV-VLPs and LPS in MDDCs. 3, I I 9 genes included in this analysis were filtered upon the criteria of showing less than $20 \%$ missing data and a minimum of 3 -fold modulation in expression. The expanded section shows nodes including genes upregulated by HIV-VLPs and LPS-4 h (top) or by HIV-VLPs and LPS (bottom). Individual genes are indicated on the right.

and prime naïve T lymphocytes [38,39]. Lymphotoxinbeta receptor (LTBR) plays a central role in the DC homeostasis in lymphoid tissues (spleen and LN), promoting and sustaining local DC replication [40]. Furthermore, a set of cytokine receptors that share a common $\gamma$ chain (IL2R, IL-7R, IL-15R, and IL-4R) were also induced and their expression may allow DCs to respond to lymphocytederived interleukins within the lymph node.

Beta-2-microglobulin (B2M) is one of the components of the multimolecular peptide-loading MHC class-I complex within the endoplasmic reticulum (ER) of DCs [41], rep- resenting the essential process for antigen presentation to cytotoxic T lymphocytes.

CD40 and TNFSF9 may act as co-stimulatory molecules which, interacting with the corresponding $\mathrm{T}$ cell expressed ligands, have been shown to play a relevant role in the activation of $T$ cells. In particular, the CD40:CD40L interaction activates the CD4+ cells to promote the sensitization of CD8+ cells as well as to induce memory CD8+ T cell proliferation $[42,43]$. ICAM-1 is required on the surface of exosomes produced by mature DCs to prime naïve $\mathrm{T}$ cells and trigger effector T-cell response [44]. 

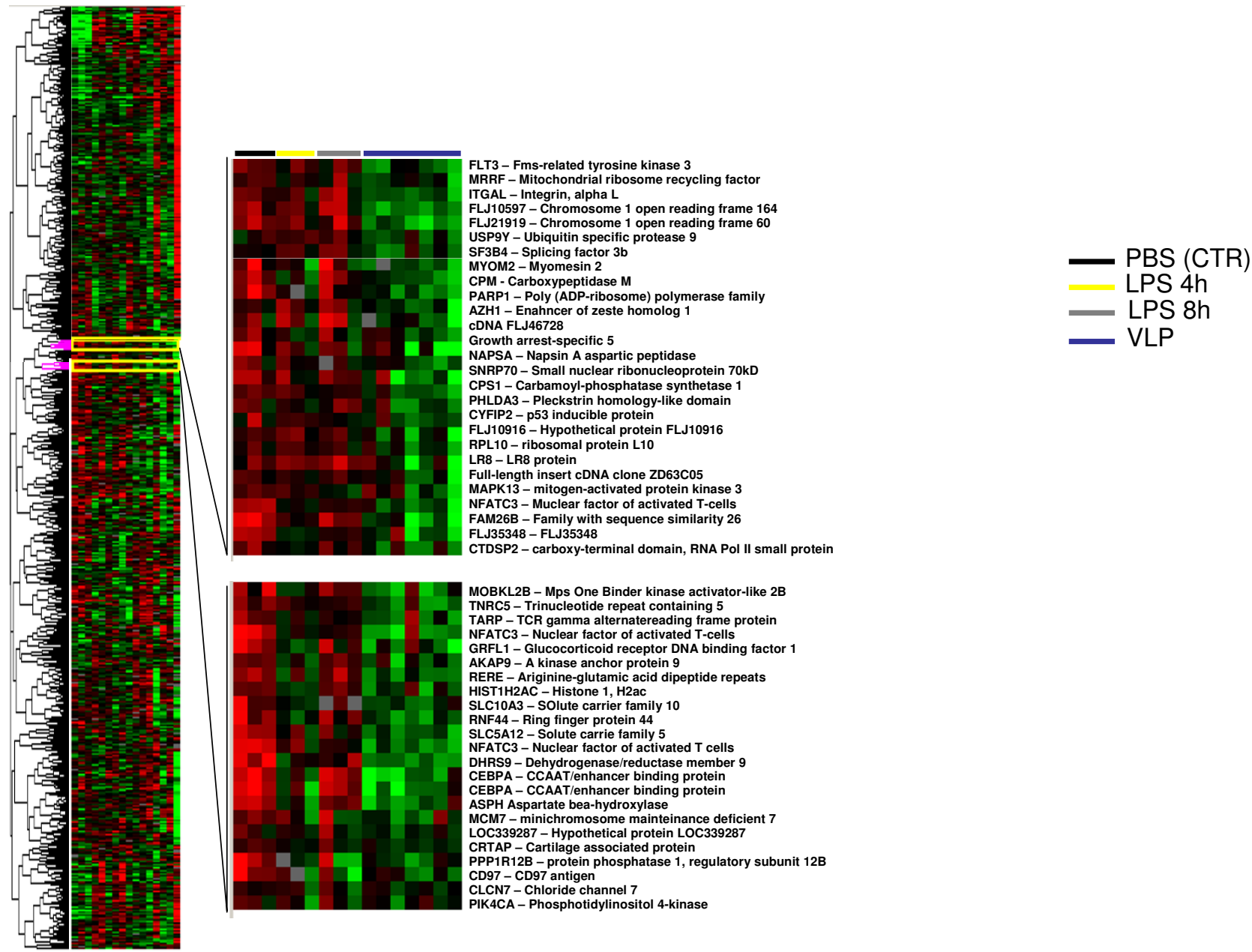

\section{Figure 7}

Supervised hierarchical clustering of genes downregulated by HIV-VLPs and LPS in MDDCs. 3, I I 9 genes included in this analysis were filtered upon the criteria of showing less than $20 \%$ missing data and a minimum of 3 -fold modulation in expression. The expanded section shows nodes including genes downregulated by HIV-VLPs only or by HIV-VLPs and LPS-4 h are shown (top and bottom, respectively). Individual genes are indicated on the right.

IL-18 has been shown to have a Th1/Th2 polarization effect. In particular, in the presence of IL-12, it enhances the IL-12-driven Th1 immune response; in the absence of IL-12, instead, IL-18 can stimulate Th2 cytokine production as well as allergic inflammation $[45,46]$.

Collectively, these changes of gene expression in response to HIV-VLPs reflect a significant cellular and immunological reprogramming of the DC.

\section{Conclusion}

The results here described confirm that baculovirus-produced HIV-VLPs induce a maturation pattern in MDDCs consistent with the one triggered by known activators, such us LPS, TNF $\alpha$ or cytokine cocktails. The genomic transcriptional profile induced by HIV-VLPs in MDDCs shows the activation of unique genes and cellular pathways compared to both PBS and LPS induction, reflecting a distinctive cellular and immunological reprogramming.

An unsupervised Eisen's clustering analysis confirm the specificity of the observation, given that the MDDCs samples derived from the HIV-VLP treatment cluster together. The only sample treated with HIV-VLPs which forms a different cluster on the basis of the 3,119 filtered genes, aggregates to the HIV-VLP samples when the differentially expressed genes are considered. This confirms that the pattern of genes specifically modulated by the HIV-VLP treatment is consistent all across the analyzed samples. Moreover, the genes involved in the transcriptional profile cluster according preferentially to the donor more than to the length of stimulation ( 4 or $8 \mathrm{hr}$ ), indicating that the 
induced modulation of transcriptional activity is effective after as early as 4 hours and is persistent for the length of the observation. Furthermore, the observed different donor susceptibility to HIV-VLP-treatment may suggest the possibility to select specific gene patterns useful for the identification of "responsive" vaccinees. This would be extremely helpful in understanding the eventual failure in individuals enrolled in the clinical trials.

Among the pathways and specific genes activated in MDDCs treated with HIV-VLPs, those directly involved in the biological functions as antigen presenting cells (APCs) have been analyzed in detail. The full functional maturation and activation of MDDCs by HIV-VLPs has been confirmed and, in particular, the activation of genes involved in cellular control (proliferation, differentiation, migration and homeostasis) as well as in functional activity (antigen presentation, $\mathrm{T}$ cell activation and Th polarization) has been observed.

The ability of the HIV-VLP, as exogenous antigen, to induce a CD8+ cytotoxic T lymphocyte (CTL) response, as previously demonstrated in vivo, is supported by the activation of genes (such as beta 2 microglobulin) involved in the antigen presentation within the context of major histocompatibility complex (MHC) class I molecules as well as in the Th1 polarization (IFN gamma and IL-18).

The presentation of an exogenous antigen in the context of major histocompatibility complex (MHC) class I molecules, to induce a CD8+ cytotoxic T lymphocyte (CTL) response, is referred to as "cross-presentation", in alternative to the "direct" or "classic" presentation route for endogenously synthesized proteins. The cross-presentation is a strategy employed only by DCs, among all the antigen presenting cells, to ensure an anti-virus CTL response also for those viruses which do not infect DCs [47]. The CD8+ DC subset seems to be primarily involved in this strategy $[48,49]$, but the molecular mechanisms underlying the cross-presentation are not yet fully elucidated [50-52].

Microarray approach allows quantitative and simultaneous analysis of gene expression of a large amount of genes and the systematic studies of expression patterns are extremely useful for identify molecular events and key pathways involved in cellular functions induced by specific stimuli. In this study, informative data on the global pattern of gene expression underlying the activation of MDDCs by HIV-VLPs at the early stages of the immune response have been obtained. They may be extremely helpful for the identification of exclusive activation markers to trace the biological effects of modifications/optimizations of the HIV-VLP vaccination strategy.

\section{References}

I. Miyanohara A, Imamura T, Araki M, Sugawara K, Ohtomo N, Matsubara $\mathrm{K}$ : Expression of hepatitis $B$ virus core antigen gene in Saccharomyces cerevisiae: synthesis of two polypeptides translated from different initiation codons. J Virol 1986, 59:176-180.

2. Gheysen D, Jacobs E, de Foresta F, Thiriart C, Francotte M, Thines D, De Wilde M: Assembly and release of HIV-I precursor Pr55gag virus-like particles from recombinant baculovirus-infected insect cells. Cell 1989, 59:103-II2.

3. Buonaguro L, Tornesello ML, Buonaguro FM: Virus-like particles (VLPs) as anti-viral vaccines: an effective approach for a HIVI vaccine strategy. ASHI Quarterly 3rd Quarter 2005, I0:.

4. Noad R, Roy P: Virus-like particles as immunogens. Trends Microbiol 2003, I I:438-444.

5. Buonaguro L, Buonaguro FM, Tornesello ML, Mantas D, Beth-Giraldo E, Wagner R, Michelson S, Prevost M-C, Wolf H, Giraldo G: High efficient production of Pr55gag Virus-like Particles expressing multiple HIV-I epitopes, including a gpI20 protein derived from an Ugandan HIV-I isolate of subtype A. Antiviral Research 2001, 49:35-47.

6. Buonaguro L, Del Gaudio E, Monaco M, Greco D, Corti P, BethGiraldo E, Buonaguro FM, Giraldo G: Heteroduplex mobility assay and phylogenetic analysis of $\mathrm{V} 3$ region sequences of HIV I isolates from Gulu - Northern Uganda. J Virol 1995, 69:797|-798।.

7. Buonaguro L, Buonaguro FM, Russo F, Tornesello ML, Beth-Giraldo $E$, Wagner $R$, Wolf $H$, Giraldo $G$ : A novel gp I 20 sequence from an HIV-I isolate of the A clade identified in North Uganda. AIDS Res Hum Retroviruses 1998, I 4: I 287-I 289.

8. Buonaguro L, Racioppi L, Tornesello ML, Arra C, Visciano ML, Biryahwaho B, Sempala SDK, Giraldo G, Buonaguro FM: Induction of neutralizing antibodies and CTLs in Balb/c mice immunized with Virus-like Particles presenting a gp 120 molecule from a HIV-I isolate of clade A (HIV-VLP $\mathbf{A}_{\mathbf{A}}$ ). Antiviral Research 2002, 54:|89-20|

9. Buonaguro L, Visciano ML, Tornesello ML, Tagliamonte M, Biryahwaho $B$, Buonaguro FM: Induction of systemic and mucosal cross-clade neutralizing antibodies in BALB/c mice immunized with human immunodeficiency virus type I clade A virus-like particles administered by different routes of inoculation. J Virol 2005, 79:7059-7067.

10. Heath WR, Carbone FR: Cross-presentation in viral immunity and self-tolerance. Nat Rev Immunol 200 I, I: I 26-I 34.

II. Moron VG, Rueda P, Sedlik C, Leclerc C: In vivo, dendritic cells can cross-present virus-like particles using an endosome-tocytosol pathway. J Immunol 2003, I 7 I:2242-2250.

12. Banchereau J, Steinman RM: Dendritic cells and the control of immunity. Nature 1998, 392:245-252.

13. Rescigno M, Granucci F, Citterio S, Foti M, Ricciardi-Castagnoli P: Coordinated events during bacteria-induced DC maturation. Immunology Today 1999, 20:200-203.

14. Sparwasser T, Koch ES, Vabulas RM, Heeg K, Lipford G, Ellwart JW, Wagner H: Bacterial DNA and immunostimulatory CpG oligonucleotides trigger maturation and activation of murine dendritic cells. European Journal of Immunology 1998, 28:2045-2054.

15. Cella M, Salio M, Sakakibara Y, Langen H, Julkunen I, Lanzavecchia A: Maturation, activation and protection of dendritic cells induced by double-stranded RNA. J Exp Med 1999, | 89:82|-829.

16. Verdijk RM, Mutis T, Esendam B, Kamp J, Melief CJ, Brand A, Goulmy E: Polyribosinic polyribocytidylic acid (poly(I:C)) induces stable maturation of functionally active human dendritic cells. J Immunol 1999, |63:57-6I.

17. Cella M, Scheidegger D, Palmer-Lehmann K, Lane P, Lanzavecchia A, Alber $\mathrm{G}$ : Ligation of CD40 on dendritic cells triggers production of high levels of interleukin- $I 2$ and enhances $T$ cell stimulatory capacity: T-T help via APC activation. J Exp Med 1996, I 84:747-752.

18. Sallusto F, Lanzavecchia A: Understanding dendritic cells and $\mathbf{T}$ lymphocyte traffic through the analysis of chemokine receptor expression. Immunology Review 2000, I77: I34-I40.

19. Rogge L, Bianchi E, Biffi M, Bono E, Chang SY, Alexander H, Santini C, Ferrari G, Sinigaglia L, Seiler M, et al:: Transcript imaging of the development of human $T$ helper cells using oligonucleotide arrays. Nat Genetics 2000, 25:96-101. 
20. Sciammas R, Davis MM: Modular nature of Blimp-I in the regulation of gene expression during $\mathbf{B}$ cell maturation. J Immunol 2005, I 72:5427-5240.

21. Messmer D, Messmer B, Chiorazzi N: The global transcritpional maturation program and stimuli-specific gene expression profiles of human myeloid dendritic cells. International Immunology 2003, 15:49|-503.

22. Tureci O, Bian H, Nestle FO, Raddrizzani L, Rosinski JA, Tassis A, Hilton H, Walstead M, Sahin U, Hammer J: Cascades of transcriptional induction during dendritic cell maturation revealed by genome-wide expression analysis. FASEB 2003, I 7:836-847.

23. Huang $Q$, Liu D, Majewski P, Schulte LC, Korn JM, Young RA, Lander $E S$, Hacohen N: The plasticity of dendritic cell responses to patogens and their components. Science 200I, 294:870-875.

24. Langenkamp A, Messi M, Lanzavecchia A, Sallusto F: Kinetics of dendritic cell activation: impact on priming of ThI, Th2 and polarization T cells. Nature Immunology 2000, I:3 I I-3 I6.

25. Nagorsen D, Deola S, Smith K, Wang E, Monsurro V, Zanovello P, Marincola FM, Panelli MC: Polarized monocyte response to cytokine stimulation. Genome Biology 2005, 6:RI5.

26. Wang E, Miller LD, Ohnmacht GA, Liu ET, Marincola FM: High-fidelity mRNA amplification for gene profiling. Nature Biotechnology 2000, 18:457-459.

27. Wang E, Miller LD, Ohnmacht GA, Mocellin S, Perez-Diez A, Petersen D, Zhao Y, Simon R, Powell JI, Asaki E, Alexander HR, Duray PH, Herlyn M, Restifo NP, Liu ET, Rosenberg SA, Marincola FM: Prospective molecular profiling of melanoma metastases suggests classifiers of immune responsiveness. Cancer Res 2005, 62:358I-3586.

28. Eisen MB, Spellman PT, Brown PO, Botstein D: Cluster analysis and display of genome-wide expression patterns. Proc Natl Acad Sci USA 1998, 95:|4863-|4868.

29. Ross DT, Scherf U, Eisen MB, Perou CM, Rees C, Spellman PT, lyer V, Jeffrey SS, Van de Rijn M, Waltham M, et al.: Systematic variation in gene expression patterns in human cancer cell lines. Nat Genetics 2000, 24:227-235.

30. Aaronson DS, Horvath CM: A road map for those who don't know JAK-STAT. Science 2002, 296: I653-I655.

31. Darnell JE, Kerr IM, Stark GR: Jak-STAT pathways and transcriptional activation in response to IFNs and other extracellular signaling proteins. Science 1994, 264:1415-1421.

32. Caux C, Dezutter-Dambuyant C, Schmitt D, Banchereau J: GM-CSF and TNF-alpha cooperate in the generation of dendritic Langerhans cells. Nature 1992, 360:258-26I.

33. Inaba K, Inaba M, Romani N, Aya H, Deguchi M, Ikehara S, Muramatsu S, Steinman RM: Generation of large numbers of dendritic cells from mouse bone marrow cultures supplemented with granulocyte/macrophage colony-stimulating factor. J Exp Med 1992, I 76: 1693-1702.

34. Li G, Kim YJ, Broxmeyer H: Macrophage colony-stimulating factor drives cord blood monocyte differentiation into ILI O(high)IL-I 2 absent dendritic cells with tolerogenic potential. J Immunol 2005, I 74:4706-47I7.

35. Boulay F, Tardif M, Brouchon L, Vignais P: The human Nformylpeptide receptor. Characterization of two cDNA isolates and evidence for a new subfamily of G-protein-coupled receptors. Biochemistry 1990, 29: I II23-III33.

36. Deng X, Ueda H, Su SB, Gong W, Dunlop NM, Gao JL, Murphy P, Wang JM: A synthetic peptide derived from human immunodeficiency virus type I gp I 20 downregulates the expression and function of chemokine receptors CCR5 and CXCR4 in monocytes by activating the 7-transmembrane G-proteincoupled receptor FPRL I/LXA4R. Blood 1999, 94: I I65-II73.

37. Su SB, Gong W, Gao JL, Shen WP, Grimm MC, Deng X, Murphy P, Oppenheim J, Wang JM: T20/DPI 78, an ectodomain peptide of human immunodeficiency virus type I $\mathrm{gpl}$, is an activator of human phagocyte $\mathbf{N}$-formyl peptide receptor. Blood 1999, 93:3885-3892

38. Jarrossay D, Napolitani G, Colonna M, Sallusto F, Lanzavecchia A: Specialization and complementarity in microbial molecule recognition by human myeloid and plasmacytoid dendritic cells. European Journal of Immunology 2001, 3 I:3388-3393.

39. Pendl GG, Robert C, Steinert M, Thanos R, Eytner R, Borges E, Wild MK, Lowe JB, Fuhlbrigge RC, Kupper TS, et al.: Immaure mouse dendritic cells enter inflamed tissue, a process that requires
E- and P-selectin, but not P-selectin glycoprotein ligand I. Blood 2002, 99:946-956.

40. Kabashima K, Banks TA, Ansel KM, Lu TT, Ware CF, Cyster JG: Intrinsic lymphotoxin-beta receptor requirement for homeostasis of lymphoid tissue dendritic cells. Immunity 2005, 22:439-450.

4I. Lankat-Buttgereit B, Tampe R: The transporter associated with antigen processing: function and implications in human diseases. Physiological Reviews 2002, 82: |87-204.

42. Mackey MF, Gunn JR, Ting PP, Kikutani H, Dranoff G, Noelle RJ, Barth $\mathrm{RJ}$ : Protective immunity induced by tumor vaccines requires interaction between CD40 and its ligand, CDI54. Cancer Research 1997, 57:2569-2574.

43. Li Q, Grover AC, Donald EJ, Carr A, Yu J, Whitfiled J, Nelson M, Takeshita N, Chang AE: Simultaneous Targeting of CD3 on T Cells and CD40 on B or Dendritic Cells Augments the Antitumor Reactivity of Tumor-Primed Lymph Node Cells. J Immunol 2005, I 75:|424-|432.

44. Segura E, Nicco C, Lombard B, Veron P, Raposo G, Batteux F, Amigorena $S$, Thery C: ICAM-I on exosomes from mature dendritic cells is critical for efficient naive T-cell priming. Blood 2005, 106:216-223.

45. Nakanishi K, Yoshimoto T, Tsutsui H, Okamura H: Interleukin- 18 regulates both ThI and Th2 responses. Annual Review in Immunology 2001, 1 9:423-474.

46. Yoshimoto T, Takeda K, Tanaka T, Ohkusu K, Kashiwamura S, Okamura H, Akira S, Nakanishi K: IL-I 2 Up-Regulates IL-I 8 Receptor Expression on T Cells, Th I Cells, and B Cells: Synergism with IL-I 8 for IFN-gamma Production. J Immunol 1998, | 6 | :3400-3407.

47. Heath WR, Belz GT, Behrens GM, Smith CM, Forehan SP, Parish IA Davey GM, Wilson NS, Carbone FR, Villadangos JA: Cross-presentation, dendritic cell subsets, and the generation of immunity to cellular antigens. Immunol Rev 2004, 199:9-26.

48. Schulz O, Reis E, Sousa C: Cross-presentation of cell-associated antigens by CD8alpha+ dendritic cells is attributable to their ability to internalize dead cells. Immunology 2002, I07:183-189.

49. lyoda T, Shimoyama S, Liu K, Omatsu Y, Akiyama Y, Maeda Y, Takahara K, Steinman RM, Inaba K: The CD8+ dendritic cell subset selectively endocytoses dying cells in culture and in vivo. Exp Med 2002, 195: I 289-1302.

50. Guermonprez P, Saveanu L, Kleijmeer M, Davoust J, Van Endert P, Amigorena S: ER-phagosome fusion defines an MHC class I cross-presentation compartment in dendritic cells. Nature 2003, 425:397-402.

5I. Ackerman AL, Kyritsis C, Tampe R, Cresswell P: Early phagosomes in dendritic cells form a cellular compartment sufficient for cross presentation of exogenous antigens. Proc Natl Acad Sci USA 2003, 100:12889-12894.

52. Houde M, Bertholet S, Gagnon E, Brunet S, Goyette G, Laplante A, Princiotta MF, Thibault P, Sacks D, Desjardins M: Phagosomes are competent organelles for antigen cross-presentation. Nature 2003, 425:402-406.

Publish with Biomed Central and every scientist can read your work free of charge

"BioMed Central will be the most significant development for disseminating the results of biomedical research in our lifetime. "

Sir Paul Nurse, Cancer Research UK

Your research papers will be:

- available free of charge to the entire biomedical community

- peer reviewed and published immediately upon acceptance

- cited in PubMed and archived on PubMed Central

- yours - you keep the copyright 